\title{
Working Amidst Covid-19: A Study Of Growth, Relatedness, and Existence among Remote Workers
}

Norhafizah Amir, Susanna Bithiah Varma, Siti Fatimah Mohamad Razi, Noor Hanim Rahmat, Ira Syaqira Sukimin, Eugenie Anyau

To Link this Article: http://dx.doi.org/10.6007/IJARBSS/v11-i7/10501

DOI:10.6007/IJARBSS/v11-i7/10501

Received: 24 May 2021, Revised: 29 June 2021, Accepted: 18 July 2021

Published Online: 30 July 2021

In-Text Citation: (Amir et al., 2021)

To Cite this Article: Amir, N., Varma, S. B., Razi, S. F. M., Rahmat, N. H., Sukimin, I. S., \& Anyau, E. (2021). Working Amidst Covid-19: A Study Of Growth, Relatedness, and Existence among Remote Workers. International Journal of Academic Research in Business and Social Sciences, 11(7), 1478-1491.

Copyright: (c) 2021 The Author(s)

Published by Human Resource Management Academic Research Society (www.hrmars.com)

This article is published under the Creative Commons Attribution (CC BY 4.0) license. Anyone may reproduce, distribute, translate and create derivative works of this article (for both commercial and non-commercial purposes), subject to full attribution to the original publication and authors. The full terms of this license may be seen at: http://creativecommons.org/licences/by/4.0/legalcode

Vol. 11, No. 7, 2021, Pg. 1478 - 1491

Full Terms \& Conditions of access and use can be found at http://hrmars.com/index.php/pages/detail/publication-ethics 


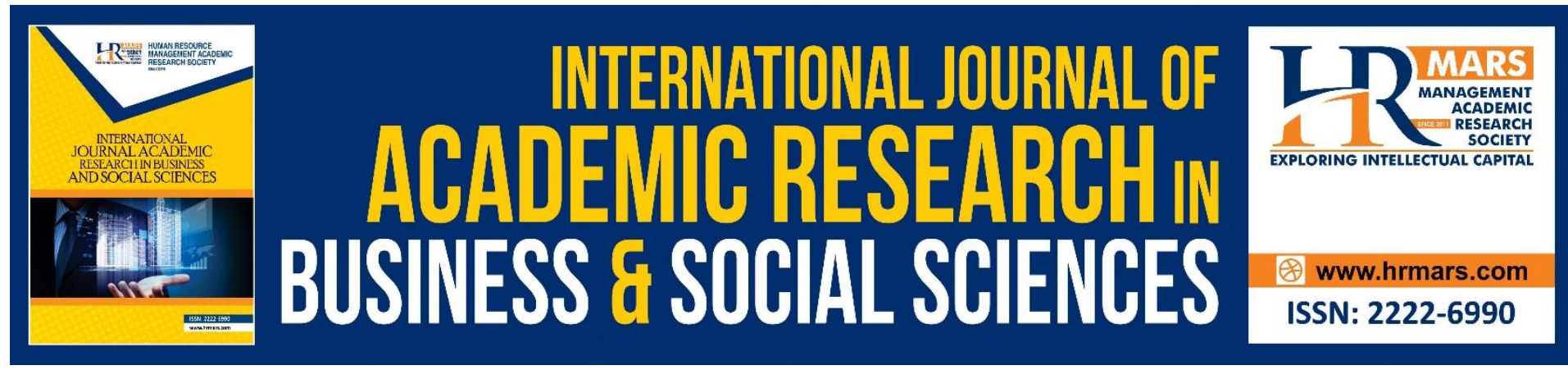

\title{
Working Amidst Covid-19: A Study Of Growth, Relatedness, and Existence among Remote Workers
}

\author{
Norhafizah Amir ${ }^{1}$, Susanna Bithiah Varma², Siti Fatimah \\ Mohamad Razi ${ }^{3}$, Noor Hanim Rahmat ${ }^{4}$, Ira Syaqira Sukimin ${ }^{5}$, \\ Eugenie Anyau ${ }^{6}$ \\ 1,2,3,5Akademi Pengjian Bahasa, Universiti Teknologi MARA Cawangan Johor, Kampus \\ Segamat, Johor Darul Ta'zim, Malaysia, ${ }^{4} A$ kademi Pengajian Bahasa, Universiti Teknologi \\ MARA, Shah Alam, Selangor, Malaysia, ${ }^{6}$ Akademi Pengajian Bahasa, Universiti Teknologi \\ Mara, cawangan Selangor, Kampus Dengkil, Dengkil, Malaysia
}

\begin{abstract}
With or without the pandemic, remote working is the new norm for many. Employees are enjoying the flexibility that remote working has to offer. Being happy then leads to better productivity for workers. Employers need to learn to trust employees more working remotely. They need to be prepared to face the difficulties that come with a "no border' world as the benefits of remote working can be better than the disadvantages. This study explores workplace needs for remote workers. 94 participants responded to the instrument. The instrument is a survey which has 4 sections. Section A has 4 items about the demographic profile. Section B has 10 items on Existence Needs through flexibility. Section C has 10 items on relatedness through work-life balance and section $D$ has 10 items on growth through work performance. Finding reveals interesting finds on the workplace needs of employees who work from home.
\end{abstract}

Keywords: Workplace Needs, Remote Workers, Existence, Relatedness, Growth

\section{Introduction}

\section{Background of Study}

Technology is now making it easier to work anywhere in the world, as long as one is connected to the Internet (Hendricks, 2014). However, The Novel Coronavirus or COVID-19 brings a new norm to people all over the world. The pandemic changed peoples' lifestyle as well as their work pattern. People start to work from home or start to work remotely. Remote work is a style of working that allows the workers to work outside their office. Other than remote work, there are also few terms used like telecommuting and teleworking. Remote workers can choose to work in any possible way that is possible for their lives. The nature of remote work permits associate workers to own a versatile work location and in 2016, the number of individuals operating remotely within the U.S. (at least part-time) increased to $43 \%$ (Darley, 2017). Before the pandemic, workers thought that remote work can save their time 
in commuting from and to work every day. They can also manage their time with the flexibility of work schedule. Nowadays, remote work has become a normal thing to do to avoid mass gathering and close contact with other colleagues.

\section{Statement of Problem}

There are various needs concerning the workplace that remote workers require. According to Raziq and Maulabakhsh (2015), a good workplace environment is determined by factors such as flexible working hours, healthy relationships among co-workers, job security and safety for employees, appreciation and acknowledgement for good performance of employees, and involvement in the decision-making matters of the organization. Alderfer (1969) emphasized that there are three core human needs that coexist to be fulfilled for their wellbeing. The first type of need is existence which is the need for good health and safety. The second type of need is relatedness which is satisfied through interpersonal relationships, affection and community concern. Employees take comfort in obtaining care, help, and support from leaders of their department (Yin \& Zeng, 2020). Lastly, is the need for growth such as acquiring more knowledge.

However, ever since employees started working remotely following the events of Covid-19, they find themselves struggling with long working hours which affects their worklife balance. Song and Gao (2019) discovered that employees were less happy and more stressed working from home. Their exhaustion levels peaked up due to the amount of telework as compared to working in the physical workplace. This is largely caused by the unlimited access of the internet which causes them to invest more time working remotely with flexible hours than usual office hours. Besides that, employees struggle with the lack of social interaction among their co-workers since telecommuting has limited them from meeting people face-to-face in real life. According to Abdullah et. al. (2020), employees who work remotely are deprived of human interaction which leads them to feel detached from the close knitted bonds that they have built priorly with their colleagues. This leads to poor work performance and a barrier in communication. Hence, this study is done to investigate what consists of a positive work climate for remote workers.

\section{Objective of the Study}

I. To investigate how existence, relatedness and growth being are parts of workplace needs.

\section{Research Questions}

Specifically, this study is done to answer the following questions;

I. How can Existence be a part of workplace needs among remote workers?

II. How can Relatedness be a part of workplace needs among remote workers?

III. How can Growth being be a part of workplace needs among remote workers?

\section{Literature Review \\ Needs at the Workplace}

There are some needs of the workers that can influence their work motivation. According to ERG theory by Alderfer (1969), employees' motivation at work is impacted by three factors (figure 1). The first factor is (a) existence and it refers to the security and physiological needs of the worker. This also includes all material needs of the workers. The second factor is (b) relatedness which refers to the self-esteem and the social needs of the 
workers. This also includes the relationships of the workers with family, friends, co-workers and employers. The third factor is (c) growth which refers to the self-actualization of the workers. This includes the desires of the workers to be more productive.

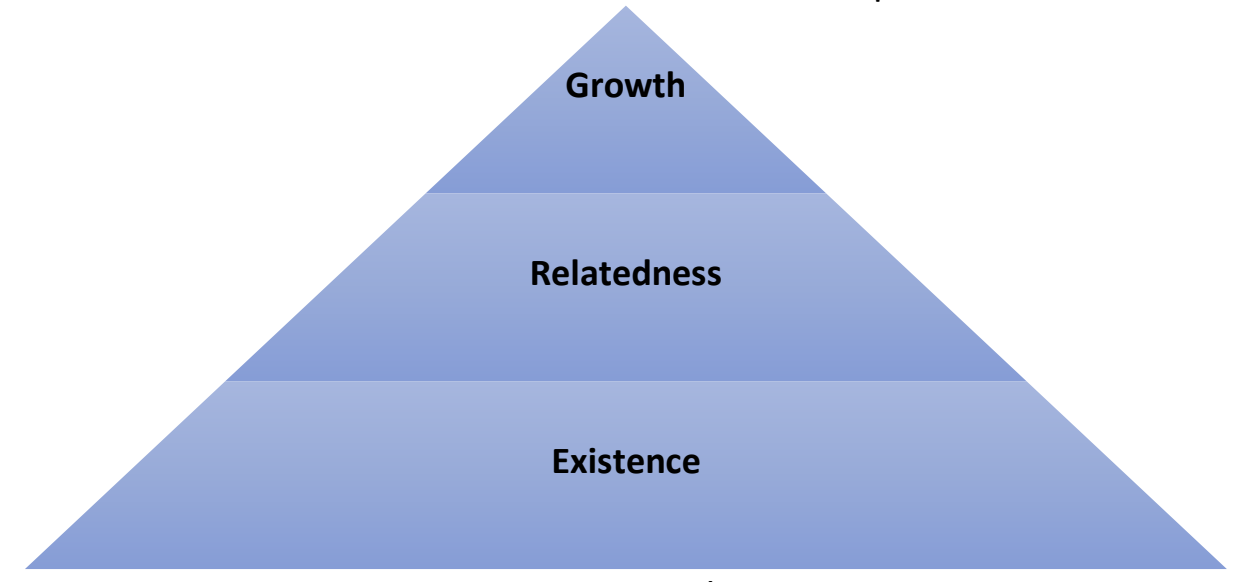

Figure 1- ERG Theory

Source: Alderfer (1969)

\section{Past Studies}

Employee satisfaction and productivity can be influenced by workplace flexibility. A study conducted by Davidescu et al. (2020) examines the connection between worker development and work time and work flexibility as relevant characteristics of property HRM, job satisfaction, and job performance among Romanians,, as well as the impact of different types of flexibility such as contractual, functional, working time, and workplace flexibility in raising overall employee job satisfaction. The analysis is based on information derived from a nationally representative survey of 220 Romanian employees. The results of the multiple correspondence analysis revealed that only one-third of Romanian employees demonstrated high levels of flexibility, whereas logistic regression analysis revealed the importance of functional flexibility, working time flexibility, and workplace flexibility in increasing employee job satisfaction.

Flexible scheduling in the workplace has an effect on employee loyalty and job satisfaction. A study conducted by Giovanis, (2019) investigates the relationship between job satisfaction, employee loyalty, and two types of flexible employment arrangements: teleworking and flexible timing. The analysis depends on knowledge derived from the work employment relations survey (WERS) in 2004 and 2011 employing a propensity score matching approach and least-squares regressions. The study also used Bayesian networks (BN) and directed acyclic graphs (DAGs) to confirm the causality between the employment types investigated and the desired outcomes. The findings support the existence of a positive causal effect from these employment arrangements: teleworking and flexible scheduling on job satisfaction and employee loyalty.

Previous research looked into the impact of precarious-compressed employment schemes for casual employees. Casual employees, according to the studies, have less flexibility in their everyday work schedules and are more likely to experience depression and social instability as a result of job insecurity. (Velayutham, 2013; Wilson and Ebert, 2013). Employees who work flexible schedules, especially remote workers, can experience fewer distractions than office workers, whose workplaces are marked by disturbances and interruptions, which trigger stress about employees' ability to produce the necessary 
outcome and reduce job satisfaction. (Makin et al., 1988; Mann et al., 2000; Luong and Rogelberg, 2005).

Work-life balance has been described as the balance between work and all other life activities that occur outside of work (Guest, 2002). There is a taxonomy of ideologies to worklife balance. Forsyth (1980) suggested that there are four categories of work-life balance. The first is (a) the absolutist. An equal distribution of your time, involvement, and satisfaction across work and life domains as suggested by Greenhaus, Collins, and Shaw (2003) is supportive of the absolutist assortment. The second category is (b) the exception's perspective which is utilitarian in nature and aims to reveal what balance works best for the greatest number of individuals (Reiter, 2007). The subjectivist being the third category (c) and (d) situationist being the fourth. Both ideologies are two perspectives in multiple iterations of balance. Specifically, the situationist perspective emphasizes trade the definition of balance to suit the individual's personal context. Moreover, balance facilitates the grouping of people per similarities in values, together with by career, gender, family structure, life stage, or financial gain level with varied definitions of work-life balance (Reiter, 2007)

Gajendran and Harrison (2007) found that distal outcomes, such as performance, job satisfaction, turnover intent, and role stress were partially mediated by perception of autonomy. After analysing 46 studies, which included 12883 employees in qualitative and quantitative research, the authors found that the telecommuting industry had small, however, beneficial effects on the employee's proximal outcomes. Gajendran and Harrison (2007) also found that distal outcomes, such as performance, job satisfaction, turnover intent, and role stress were partially mediated by perception of autonomy.

Another study by Wong and Ko (2009) was done specifically for the hospitality industry which explores the phenomenon of work-life balance through qualitative research. There is little quantitative research examining the relationships between work-life balance and the factors that achieve it. Wong and Ko (2009) revealed that hotel employees found balance when afforded adequate time from work; work-life balance support in the workplace; work commitment; scheduling flexibility; life orientation; the ability to voluntarily reduce work hours when family life demanded it; and preservation of the work and career. These qualitative findings have provided support for quantitative studies on work-life balance.

Even before the pandemic, remote work is normal to some of the companies especially those who are doing freelance work. There are always pros and cons when Working from home (WFH) for the workers. Research done by Shafizadeh et al. (2000) claims that working from home increases the productivity of the workers. A study by (2020) analysed ten research articles to discover factors that influence the productivity of the workers who work remotely. Five research articles are taken from the 2000s and the other five articles are from recent years (2019-2020). The study indicates that working from home does influence the productivity of the workers. The findings showed that while the influences of some of the factors can be either positive or negative, the influence of some of the factors depends on the characteristics and attitude of the workers and their environment.

Another research that is related to remote work is by Felstead and Henseke (2017). The study assesses the assumption that more works are being detached from the original place and that brings advantages to both employers and workers. For the growth of remote work, they use the Labour Force Survey to analyse the trend. Almost 40,000 households are contacted and 45,000 workers are interviewed. The result shows that remote working is a growing trend. This study also shows that while remote working, workers can be associated with higher organisational commitment, job satisfaction as well as job related well- being. 


\section{Conceptual Framework}

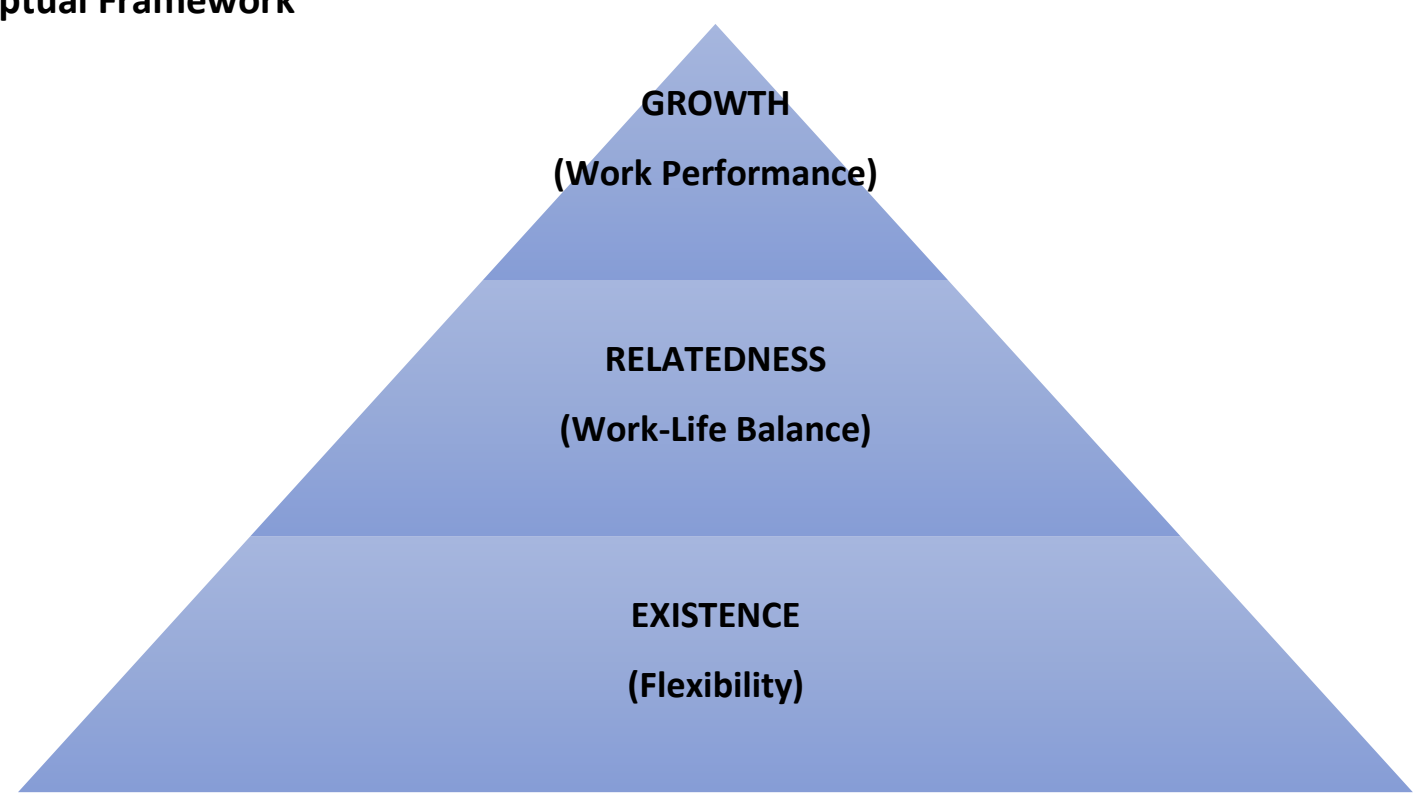

Figure 2- Conceptual Framework of the Study-Need of Remote Workers Source: Alderfer(1069); Abdullah et al., (2020)

Figure 2 presents the conceptual framework of the study. The framework is based on Alderfer's (1969) ERG theory and the factors combine the characteristics of working from home by Abdullah, Rahmat, Zawawi, Khamsah and Anuarsham (2020). At the basic level, existence through flexibility, remote workers need trust from their employers to perform their work at home. When flexibility is achieved, the remote workers would feel that they can achieve a sense of relatedness with the work while still attending to the needs of their family. This helps them to strike a work-life balance while working remotely. The highest level is growth and this is achieved through the remote workers' work performance.

\section{Methodology \\ Research Design}

This quantitative study is done to investigate how workplace needs are influenced by some factors. 94 participants responded to the instrument. The instrument is a survey adapted from Alderfer (1969) and Abdullah, Rahmat, Zawawi, Khamsah and Anuarsham (2020). The survey has 4 sections. Section A has 4 items about demographic profile. Section B has 10 items on Existence Needs through flexibility. Section $C$ has 10 items on relatedness through work-life balance and section $\mathrm{D}$ has 10 items on growth through work performance. A reliability test is done on the instrument to reveal Cronbach alpha of .906 (table 1) thus revealing a high reliability. Data is collected via google form and analysed using SPSS version 26. Findings are presented in the form of percentages and mean scores.

\section{Reliability Statistics}

\begin{tabular}{c|r}
$\begin{array}{c}\text { Cronbach's } \\
\text { Alpha }\end{array}$ & N of Items \\
\hline .906 & 30 \\
\hline
\end{tabular}

Table 1- Reliability Statistics for Instrument 


\section{Findings}

\section{Findings for Demographic Profile}

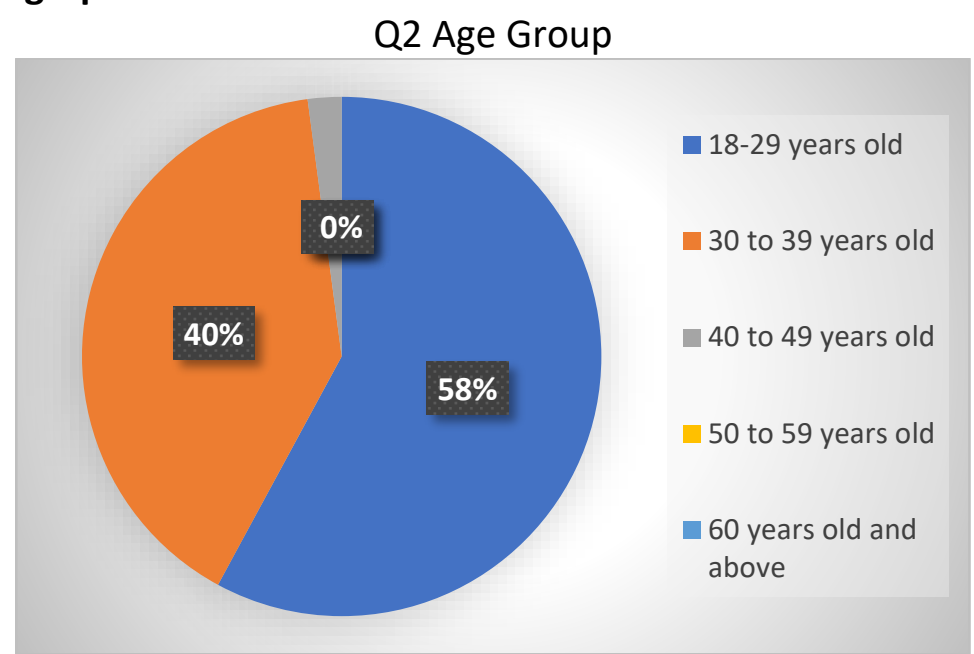

Figure 3- Percentage for Age Group

Figure 3 above shows the demographic of age groups among respondents. The majority of respondents were from the age group of $18-29$ years with $57.9 \%$. This was followed by $40 \%$ of the respondents coming from the age group of $30-39$ years and only $2.1 \%$ were from the age group of 40-49 years. There were no respondents from the last two categories of age group.

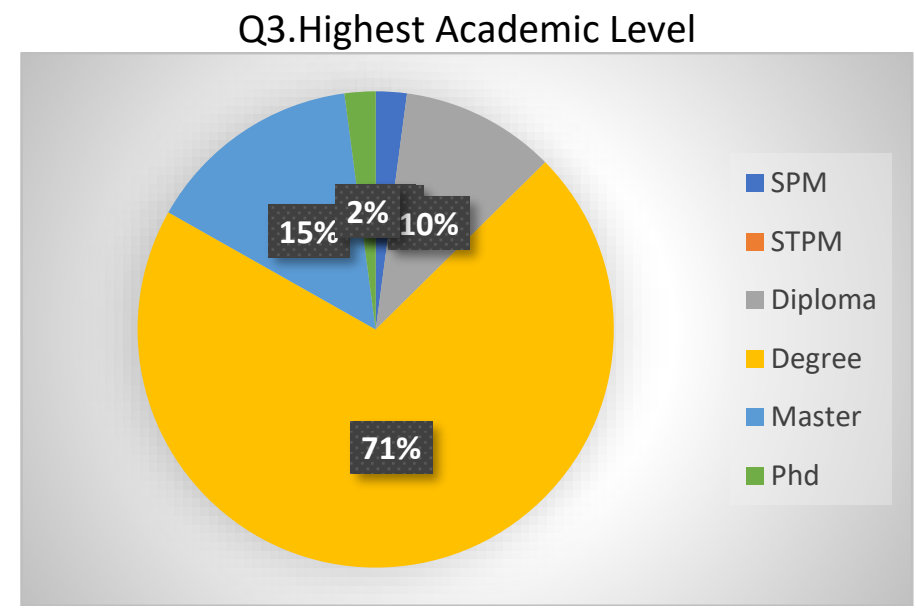

Figure 4-Percentage for Academic Level

According to figure 4 above, the highest academic level of respondents came from the category of Degree holders with $70.5 \%$, followed by the category of Master holders with $14.7 \%$. The number of Diploma holders were at $10.5 \%$. There were no respondents from the category of STPM holders. The number of PhD and SPM holders were at a tie of $2.1 \%$ respectively. 
Q4 Type of Industry

\begin{tabular}{|l|l|l|}
\hline 1 & Agricultural, Forestry and Fishing & $1.1 \%$ \\
\hline 2 & Mining & $0.0 \%$ \\
\hline 3 & Construction & $1.1 \%$ \\
\hline 4 & Manufacturing & $4.3 \%$ \\
\hline 5 & Transportation \& Public Utilities & $1.1 \%$ \\
\hline 6 & Wholesale Trade & $0.0 \%$ \\
\hline 7 & Retail Trade & $3.2 \%$ \\
\hline 8 & Finance, Insurance and Real Estate & $18.1 \%$ \\
\hline 9 & Public Services \& Administration & $6.4 \%$ \\
\hline 10 & Health Services & $1.1 \%$ \\
\hline 11 & Food \& Beverage & $1.1 \%$ \\
\hline 12 & Oil \& Gas & $3.2 \%$ \\
\hline 13 & Information Technology & $11.7 \%$ \\
\hline 14 & Education & $28.7 \%$ \\
\hline 15 & Travel \& Lodging & $13.8 \%$ \\
\hline 16 & Services & $1.1 \%$ \\
\hline 17 & Telecommunication & $1.1 \%$ \\
\hline 18 & Audit & $1.1 \%$ \\
\hline 19 & Design & $1.1 \%$ \\
\hline 20 & Nanotechnology & $1.1 \%$ \\
\hline 21 & Others (please specify) & \\
\hline
\end{tabular}

Table 2- Percentage for Type of Industry

Table 2 shows the industry in which the respondents work. Education has the highest percentage of the industry at $28.7 \%$, followed by the other industries at $19.3 \%$, which include travel and lodging, services, telecommunication, audit, design, and nanotechnology. The percentage of finance, insurance, and real estate is $18.1 \%$ and it is followed by information technology at $11.7 \%$. The percentage for public services and administration is $6.4 \%$, closely followed by manufacturing at $4.3 \%$. Agriculture, forestry and fishing, construction, transportation and public utilities, health services, and food and beverage all have the same percentage of $1.1 \%$. Mining and wholesale trade have the lowest percentages, both at $0.0 \%$. 


\section{Findings for Existence through Flexibility}

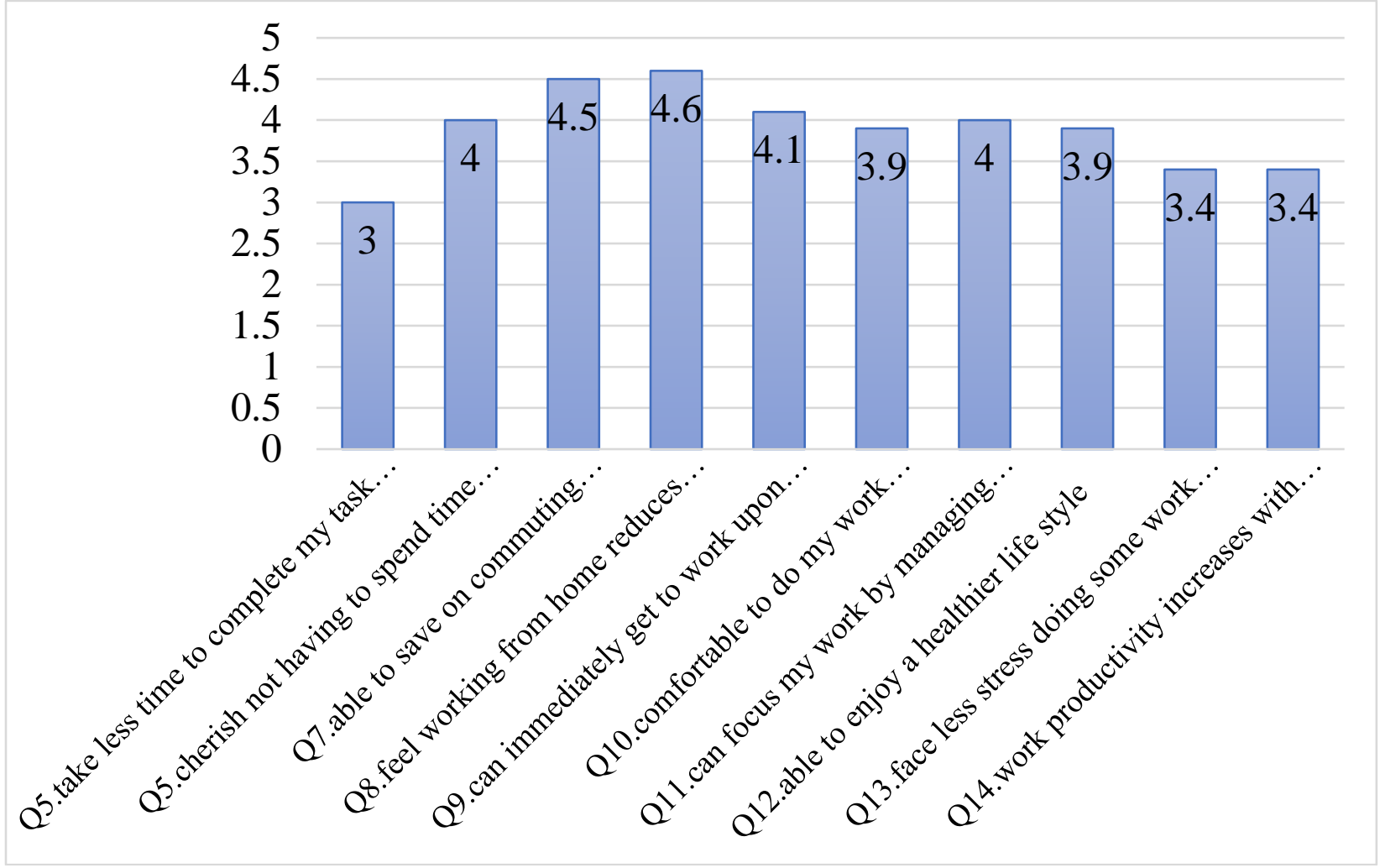

Figure 5 -mean for Existence through Flexibility

The findings for existence (flexibility) among respondents working from home are shown in the figure 5 above. According to the table, the majority of respondents agreed that working from home reduces their vehicle maintenance costs, with the highest mean value at 4.6. They mostly agreed that they can save money on commuting costs as it has the second highest mean value at 4.5 . It is then followed by a mean value of 4.1 , indicating that the respondents agreed that they could immediately get to work after waking up every day. Both Q6 and Q11 have the same mean value of 4, indicating that respondents value not having to spend time commuting to work and being able to focus on their work by managing their own schedule. Furthermore, the respondents also agreed that they are comfortable to do their work anytime and enjoy a healthier life style with both of these questions recording the same mean value of 3.9. Both Q13 and Q14, which are respondents who face less stress while working from home, and whose work productivity increases with less stress while working from home, have the second lowest mean value of 3.4. Finally, Q5, which indicates that respondents take less time to complete their tasks, has the lowest mean value of 3. 


\section{Findings for Relatedness (Work-Life Balance)}

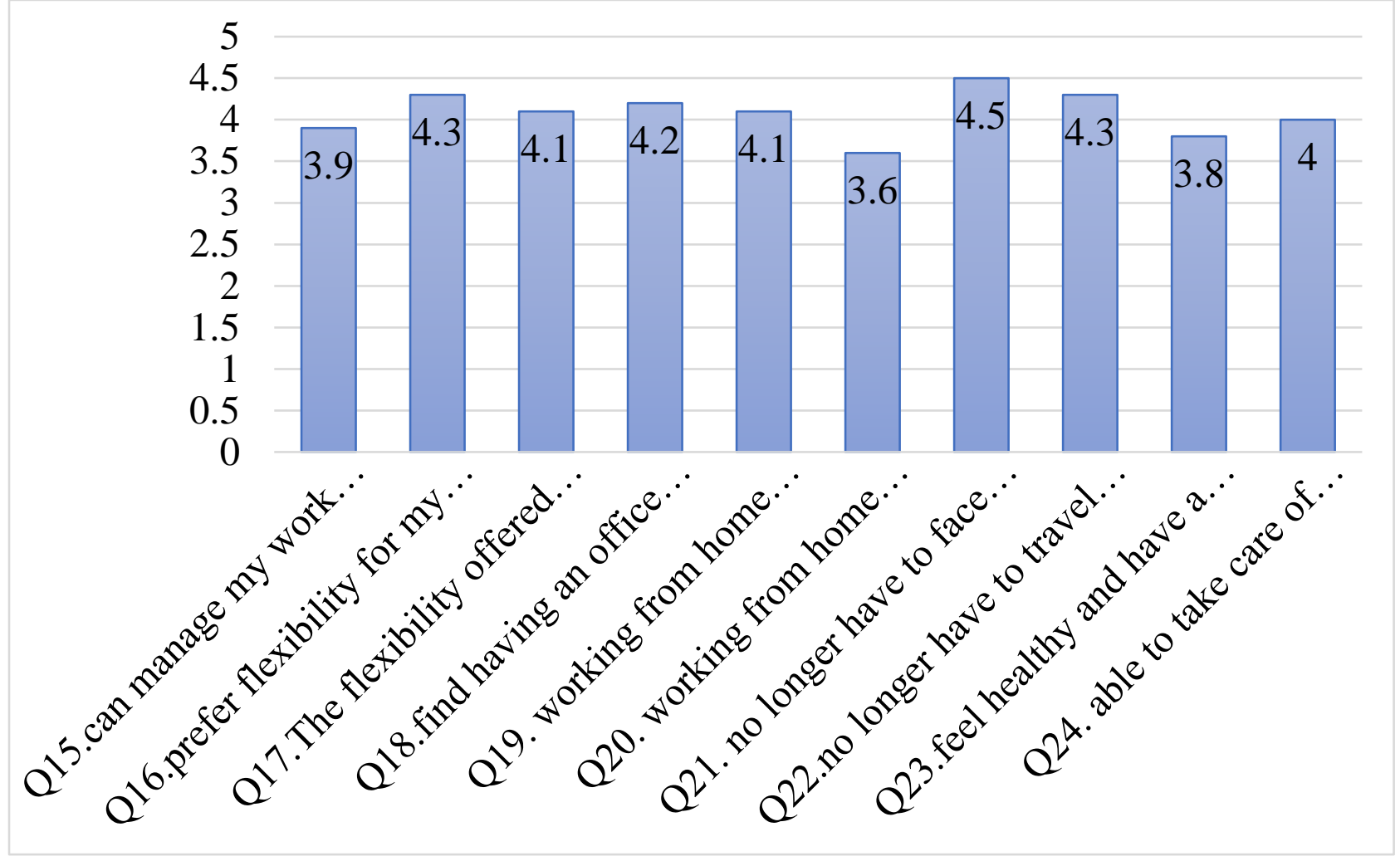

Figure 6- Mean for Relatedness through Work-Life Balance

Figure 6 presents the mean for relatedness through work-life balance. The highest mean is for Q21 were respondents "no longer have to face traffic jams" (4.5). They also reported that they "preferred flexibility for their work as they can take time off during workdays" (4.3) and they "no longer have to travel to work, therefore they are able to spend more time on their task" (4.3). Respondent also felt that the "flexibility offered to their current jab is ideal for them"(4.1). They also felt that "working from home is beneficial for them as they are able to simultaneously attend to their family's needs" (4.1). 


\section{Findings for Growth through Work Performance}

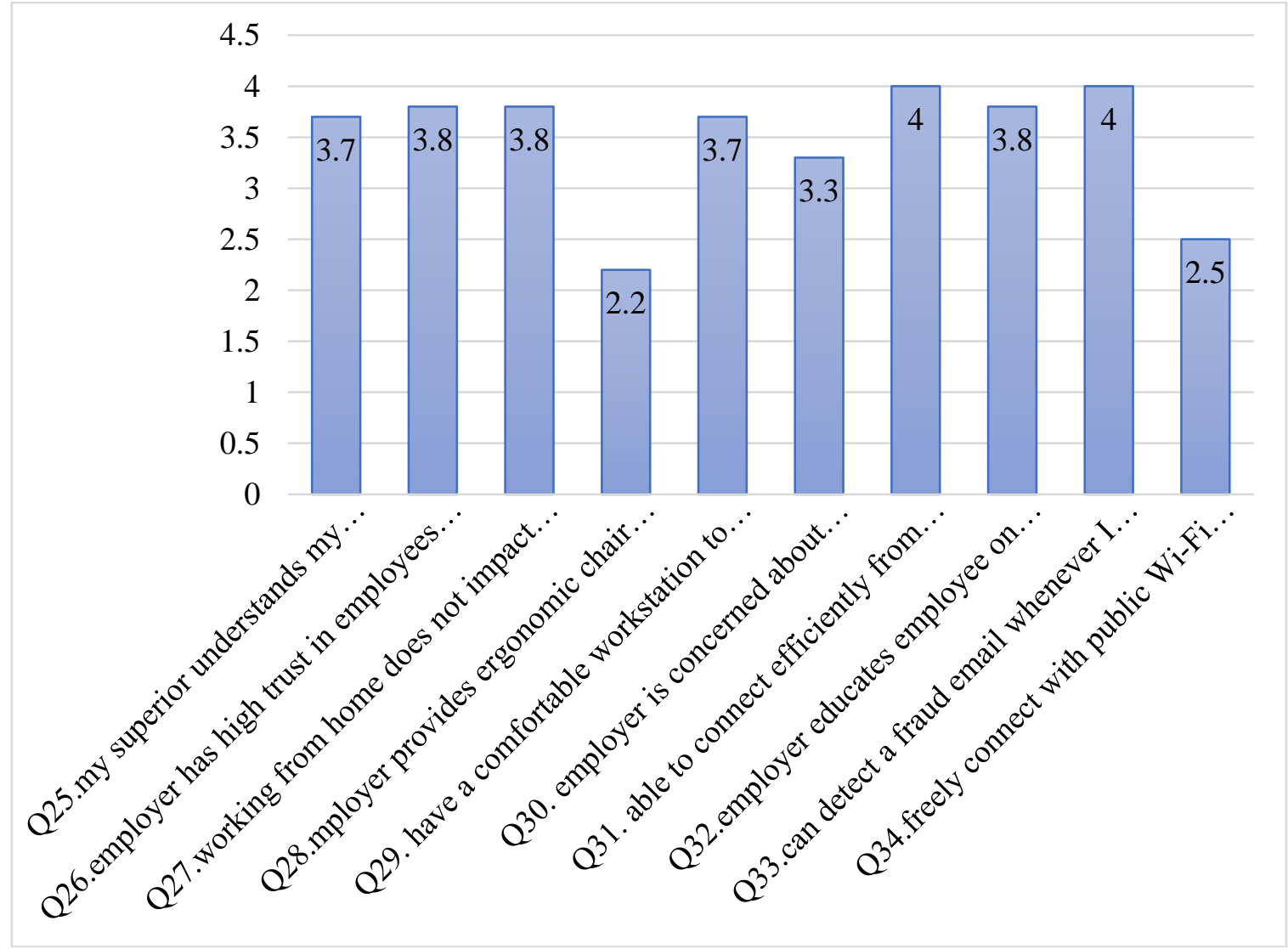

Figure 7- Mean for Growth through Work Performance

With reference to figure 7, respondents reported that they "could detect a fraud email" (4) and they are able to "connect efficiently from home using their own broadband connection" (4). They also wanted their "employer to have trust in them working from home" (3.8) , felt that "working from home did not impact their career progression" (3.8), and that their "employer educates employees on cyber security threats" (3.8). They also felt that their "superior understands my challenges while working from home" (3.7) and they had a "comfortable workstation to perform work at home"(3.7).

\section{Conclusion}

\section{Summary of Findings and Discussions}

This study has reported interesting findings about workplace needs for remote workers. It is rather surprising to note that workers actually did not like traveling to work. They may like the work but they dread travelling to and from work. Remote workers liked the idea of starting work as soon as possible and eliminating travelling time. This is also reported by Davidescu et al. (2020) and Giovanis, (2019) who also found that one thing that makes working from home works is the flexibility it offers to the workers. Next, this study also found that remote workers liked the fact that they could juggle their time between work and attending to their famiily's needs. According to Guest (2002) ,Gajendran and Harrison (2007), and Wong and Ko (2009) also reported one of the benefits of working from home is that remote workers can have a work-life balance. 


\section{Implications}

With or without the pandemic, remote working is the new norm for many. Employees are enjoying the flexibility that remote working has to offer. Being happy then leads to better productivity for workers. Employers need to learn to trust employees more working remotely. They need to be prepared to face the difficulties that come with "no border' world as the benefits for remote working can be better than disadvantages.

\section{Suggestions for Future Research}

It is suggested that future research look at more influencing factors that lead to effective remote working. Perhaps, a qualitative can be done to interview both the employers and employees to explore deeper about the pros and cons of remote working.

\section{Contribution}

This paper's main contribution is finding how existence, relatedness and growth being are parts of workplace needs especially among remote workers. The study reveals interesting findings on the workplace needs of employees who work from home.

\section{References}

Abdullah, N. A. A., Rahmat, N. H., Zawawi, F. Z., Khamsah, M. A. N., and Anuarsham, A. H. (2020) Coping with Post COVID-19: Can Work from Home ne a New Norm? European Journal of Social Science Studies, Vol 5(6), pp 61-81. https://oapub.org/soc/index.php/EJSSS/article/view/933

Alderfer, C. P. (1969). "An empirical test of a new theory of human needs". Organizational Behavior and Human Performance. 4 (2): 142-75. doi:10.1016/0030-5073(69)90004$\mathrm{X}$.

Darley, L. (2017). The future of work: Flexible work arrangement. Forbes. https://www.forbes.com/

Davidescu, A. A., Apostu, S., Paul, A., \& Casuneanu, I. (2020). Work flexibility, job satisfaction, and job performance among Romanian employees-implications for sustainable human resource management. Sustainability, 12(15), 6086. https://www.mdpi.com/2071-1050/12/15/6086/htm

Felstead, A., and Henseke, G. (2017), Assessing the growth of remote working and its consequences for effort, well-being and work-life balance. New Technology, Work and Employment, 32: 195-212. https://doi.org/10.1111/ntwe.12097

Forsyth, D. R. (1980). A taxonomy of ethical ideologies. Journal of Personality and Social Psychology, 39, 175-184. https://psycnet.apa.org/record/1981-22467-001

Gajendran, R. S., \& Harrison, D. A. (2007). The good, the bad, and the unknown about telecommuting: Meta-analysis of psychological mediators and individual consequences. Journal of Applied Psychology, 92, 1524-1541. http://doi.org/10.1037/0021- 9010.92.6.1524

Giovanis, E. (2019). Do the flexible employment arrangements increase job satisfaction and employee loyalty? Evidence from Bayesian networks and instrumental variables. Int. J. Comput. Econ. Economy, 9, 84-115. https://econpapers.repec.org/article/idsijcome/v_3a9_3ay_3a2019_3ai_3a1_2f2_3a p_3a84-115.htm

Greenhaus, J. H., Collins, K. M., \& Shaw, J. D. (2003). The relation between work family balance and quality of life. Journal of Vocational Behavior, 63, 510-531. 
https://www.polyu.edu.hk/mm/jason/doc/Greenhaus-CollinsShaw\%202003\%20JVB.pdf

Guest, D. E. (2002), Perspectives on the study of work-life balance. Social Science Information, 41(2), 255-79. https://journals.sagepub.com/doi/abs/10.1177/0539018402041002005?ssource=

Hendricks, D. (2014). Is telecommuting the wave of the future? Forbes. https://www.forbes.com

Luong, A., and Rogelberg, S. G. (2005). Meetings and more meetings: The relationship between meeting load and the daily well-being of employees. Group Dynamics: Theory, Research and Practice, 9(1), 58-67. https://psycnet.apa.org/doi/10.1037/1089-2699.9.1.58

Makin, P. J., Rout, U., and Cooper, C. L. (1988). Job satisfaction and occupational stress among general practitioners-a pilot study. Journal of the Royal College of General Practitioners, 38(312), 303-306. https://europepmc.org/article/med/3255825

Mann, S., Varey, R., and Button, W. (2000). An exploration of the emotional impact of teleworking via computer-mediated communication. Journal of Managerial Psychology, 15(7), 668-690.

https://www.emerald.com/insight/content/doi/10.1108/02683940010378054/full/h tml

Raziq, A., \& Maulabakhsh, R. (2015). Impact of working environment on job satisfaction. Procedia Economics and Finance, 23, 717-725. https://doi.org/10.1016/S2212-5671(15)00524-9

Reiter, M. (2007). Work life balance: What do you mean? The ethical ideology underpinning appropriate application. The Journal of Applied Behavioral Sciences, 43(2), 273-294. https://journals.sagepub.com/doi/10.1177/0021886306295639

Song, Y., \& Gao, J. (2020). Does telework stress employees out? A study on working at home and subjective well-being for wage/salary workers. Journal of Happiness Studies, 21(7), 2649-2668. https://doi.org/10.1007/s10902-019-00196-6

Velayutham, S. (2013). Precarious experiences of Indians in Australia on 457 temporary work visas. Economic and Labour Relations Review, 24(3), 340-361. https://journals.sagepub.com/doi/abs/10.1177/1035304613495268?journalCode=el ra

Wilson, S., and Ebert, N. (2013). Precarious work: economic, sociological and political perspectives. Economic and Labour Relations Review, 24(3), 263-279. https://journals.sagepub.com/toc/elra/24/3

Shafizadeh, K. R., Mokhtarian, P. L., Niemeier, D. A., and Salomon, I. (2000), 'The Costs and Benefits of Home-Based Telecommuting', UC Berkeley: California Partners for Advanced Transportation Technology. https://escholarship.org/uc/item/49c1n7hg

Thorstensson, E. (2020). The Influence of Working from Home on Employees' Productivity: Comparative document analysis between the years 2000 and 2019-2020 (Dissertation). http://urn.kb.se/resolve?urn=urn:nbn:se:kau:diva-78743

Wong, S. C., \& Ko, A. (2009). Exploratory study of understanding hotel employees' perception on work-life balance issues. International Journal of Hospitality Management 28, 195 203. https://psycnet.apa.org/record/2009-02289-002

Yin, X., \& Zeng, L. (2020). A study on the psychological needs of nurses caring for patients with coronavirus disease 2019 from the perspective of the existence, relatedness, and 
INTERNATIONAL JOURNAL OF ACADEMIC RESEARCH IN BUSINESS AND SOCIAL SCIENCES

Vol. 11, No. 7, 2021, E-ISSN: 2222-6990 @ 2021 HRMARS

growth theory. International Journal of Nursing Sciences, 7(2), 157-160.

https://doi.org/10.1016/j.ijnss.2020.04.002 